\title{
Fitness of the marine parasitic nematode Anisakis simplex S. str. in temperate waters of the NE Atlantic
}

\author{
Elvira A bollo르, Stefano D'A melio², Santiago Pascual ${ }^{1, *}$
}

1Área de Parasitología, G rupo PB2, Facultad de Ciencias, Universidad de Vigo, 36200 Vigo, Spain
2Institute of Parasitology, University of Rome 'La Sapienza', P. Ie Aldo M oro, 5, 00185 Rome, Italy

\begin{abstract}
In temperate waters of the NE Atlantic, third-stage larvae of Anisakis simplex sensu stricto collected from 3 paratenic host species were identified by restriction fragment length polymorphisms. The condition of wild larval infrapopulations was assessed by examining morphometric and growth characteristics. The differentiation patterns and the excretory/secretory products of larvae grown in vitro were al so examined. An extensive morphometric, growth and differentiation variability was found between parasite larvae collected from different paratenic host sources. Nematode infrapopulation larvae from the squid comprise those smaller individuals with the lowest values of survival rates and moult success. It may be then concluded that the fitness of A. simplex s. str. larvae is not the best possible in the squid, which impaired the competitiveness of the parasite and its chances of developing into an adult. This suggests that the microenvironments impaired by the paratenic host may provide larval infrapopulations with unique ecological factors probably influencing its recruitment to the final host populations.
\end{abstract}

KEY WORDS: A nisakis simplex s. str. · Fitness · Recruitment

Resale or republication not permitted without written consent of the publisher

\section{INTRODUCTION}

The common whaleworm or herringworm includes an important and diverse array of parasitic organisms, with a certain degree of specificity in their geographic distribution and their host preference in major areas and fisheries of the marine ecosystem (M attiucci et al. 1997). Recent studies on Anisakis simplex, the casual agent of human anisakiasis as larvae, show the existence of at least 3 reproductively isolated sibling species, differing in their genetic structure, life history and geographic distribution (Nascetti et al. 1983, 1986, Mattiucci et al. 1997).

Parasite recruitment, usually defined as the number of parasitic larvae from a single breeding that enter the host population, might be expected to relate to the total biomass of the spawners comprising a stock. The low predictive power of stock-recruitment relationships characterized by high variance, and the difficulties associated with predicting recruitment with accuracy,

*Corresponding author: E-mail: spascual@uvigo.es has been a central problem in anisakid population models (Des Clers 1990), which are a key element for the epidemiological control of the so-called 'fish nematode problems' in nature (ICES-WGPDMOC 1995). Since few of the many eggs produced by anisakids eventually give rise to adults (Smith 1984), it is believed that small changes in the mortality rates of the larval stages can lead to the observed high variability in recruitment. Although there has been substantial controversy over the ontogenetic stage at which recruitment is determined, the third-larval stage is still considered important in this respect because it is the stage infective to the final host in which the adults are formed.

A ccording to M attiucci et al. (1997) all the samples of Anisakis simplex s. str. from the Atlantic Ocean were in Hardy-Weinberg equilibrium and no significant differences were found between samples collected in different years or in different paratenic hosts at the same locality. These authors stated that because of the homogenizing effects of gene flow, enhanced by the high vagility of intermediate/paratenic and definitive 
hosts, a remarkable genetic homogeneity is detected within A. simplex s.str. However, because of the 2layer environment defined by Pavlovsky (1934) many biological and physical factors can interact to affect the condition and mortality of Anisakis larvae. Physical processes have often been suggested as the main sources of larval mortality in the ocean (Smith 1983a, Likely \& Burt 1989, Burt et al. 1990, Pascual et al. 1996). On the other hand, differential growth within the microenvironment may also be important because it determines the time of moult and ecdysis of infective larvae and thus the length of time the larvae are susceptible to any mortality source mostly related to the host immunological responses (Abollo 1999).

The study of condition is believed to be a good indicator of the general 'well-being or fitness' of the population under consideration. The aim of this paper is to determine the role of the host species inducing intraspecific variability in some expressions of this fitness related to the success of establishing of Anisakis simplex s. str. larval infrapopulations in the final host.

\section{MATERIALS AND METHODS}

Collection of larvae. Post-recruit specimens of the blue whiting Micromesistius poutassou $(n=100)$, horse mackerel Trachurus trachurus $(n=100)$, and broadtailed short-finned squid Todaropsis eblane $(n=100)$, were collected by fishermen in the Galician fishing grounds $\left(42^{\circ} 05^{\prime}-45^{\circ} 15^{\prime} \mathrm{N}, 070^{\circ} 00^{\prime}-09^{\circ} 20^{\prime} \mathrm{W}\right)$. All specimens were placed on flake ice and transported to the laboratory where they were examined on arrival while still fresh.

Delicate capsules are present around some larvae in marine fish only $34 \mathrm{~h}$ after infection (Smith 1974). Following these authors, and according to Abollo (1999) and Pascual et al. (1999), only those 'long-term persistent' encapsulated Anisakis simplex s. str. larvae inhabiting the preferred site of infection (liver, Micromesistius poutassou; stomach, Trachurus trachurus and Todaropsis eblanae) were removed from surrounding host tissue. Furthermore, according to Smith (1984) the length distribution of younger herringworm larvae did not differ significantly from that of older larvae; thus, the size of the host was not considered in the analysis. Anisakis larvae were then randomly collected from many hosts individuals to avoid intraspecific variability related to infrapopulation subdivision in nature.

PCR-based Restriction Fragment Length Polymorphisms (PCR-RFLP) analysis. PCR-RFLP analysis of the rDNA has been identified as a useful approach for the accurate identification of sibling species of the complex Anisakis simplex (D'Amelio et al. 2000). The method was used to falsify the hypothesis that the dif- ferences observed in the fitness of Anisakis from squid and fishes may be biased by taxonomic differences in the Anisakis taxa involved.

DNA extraction was performed according to the protocol proposed by Holmes \& Bonner (1973). Two conserved primers, i.e.: A (forward), GTCGAATTCGTAGGTGAACCTGCGGAAGGATCA; and B, GCCGGATCCGAATCCTGGTTAGTTTCTTTT-CCT (Bachellerie \& Qu 1993), were used in PCR to amplify an rDNA region between the $3^{\prime}$ end of the small subunit rRNA and the $5^{\prime}$ end of the large subunit rRNA genes, spanning the internal transcribed spacer 1 , the 5.8 S subunit and the internal transcribed spacer 2. PCR amplifications were performed for each reaction, starting from 10 to $20 \mathrm{ng}$ of DNA template, using $0.5 \mu \mathrm{l}$ Amplitaq Gold Polymerase ( $5 \mathrm{U} \mu^{-1}$, Perkin-Elmer), $10 \mu$ Gene A mp 10× PCR Buffer II (Perkin- Elmer), $10 \mu \mathrm{l}$ of $\mathrm{M} \mathrm{gCl}_{2}$, $25 \mathrm{mM}$ (Perkin-Elmer), $8 \mu \mathrm{l}$ dNTPs (dCTP, dGTP, dATP, dTTP) $2.5 \mathrm{mM}$ each, $0.3 \mu \mathrm{l}$ of each primer,

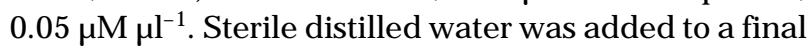
volume of $100 \mu \mathrm{l}$. The PCR conditions were as follows: $10 \mathrm{~min}$ at $95^{\circ} \mathrm{C}, 30$ cycles of $30 \mathrm{~s}$ at $95^{\circ} \mathrm{C}, 30 \mathrm{~s}$ at $55^{\circ} \mathrm{C}$ and $75 \mathrm{~s}$ at $72^{\circ} \mathrm{C}$ and followed by a final elongation of $7 \mathrm{~min}$ at $72^{\circ} \mathrm{C}$. A negative control, containing distilled water, was included in each amplification in order to detect any contaminating DNA. Following amplification, samples were subjected to electrophoresis in 1\% agarose gel. No specific bands were detected and therefore amplicons were directly subjected to RFLP analyses, using 6 individual restriction enzymes: Alul, Hhal, Hinfl, Mbol, Rsal and Taql. After digestion, fragments were separated by electrophoresis on a $2 \%$ agarose gel.

Morphometric analysis. As suggested by Berland (1961), Fagerholm (1979) and Valero et al. (1991), the sample size and nature, the fixation and clearing method and the measurement methodology were standardized in order to discriminate between morphometric and/or growth variations due to the parasite's intraspecific variability and those due to host (i.e. microenvironment) influences. Quantitative measurements of body structures by light microscopy (LM) were used to evaluate allometric growth parameters of A nisakis larvae from different host species. In order to limit manual operations, digital images of single worm structures, ranging from $\times 40$ to $\times 400$ magnification, were recorded by a CDD camera fitted onto a microscope, and then digitized and processed by a filtering operation on a PC. After separation of worms from the image background, the pixel positions of the worm outline were analysed by algorithms to describe size characteristics. To this end, morphometric data were collected on $75 \mathrm{~A}$. simplex s. str. larvae collected from the 3 host source groups ( 25 per host) using the Image Analysis System IBAS 2000. Eight measurements and 
3 indices (Koyama et al. 1969) were analysed on cleared specimens: total body length (BL), maximum body width (BW), oesophagus length $(\mathrm{OL})$, oesophagus width $(\mathrm{OW})$, ventriculus length $(\mathrm{VL})$, ventriculus width $(V W)$, tail length (from anus to tip of tail; $T L$ ), the distance of the mouth to nerve ring (MN), alfa ( $\alpha=B L$ $\left.B W^{-1}\right)$, beta $\left(\beta=B L ~ O L^{-1}\right)$, beta $3\left(\beta_{3}=B L V L^{-1}\right)$, gamma $\left(\gamma=\mathrm{BL} \mathrm{TL^{-1 }}\right)$. Non-parametric tests were used to discriminate host-induced variability in morphometric variables. In addition, a comparison of regression lines describing allometric relationships of larvae from different host source was assessed by means of analyses of covariance (ANCOVA). Furthermore, data were subjected to a stepwise forward discriminant analysis to select a subset of variables. The variables selected were then subjected to a canonical discriminant analysis (CDA). Mahalanobis distances between individual observations were calculated. Individual observations were subsequently allocated to the group for which they had the minimal Mahalanobis distance. These analyses were carried out with the raw data matrix.

In vitro culture. In vitro cultures were performed to determine the role of the microenvironment as a factor inducing the observed morphometric variability of wild larval infrapopulations. Worm larvae collected from the 3 host source groups were cultured in the same media and then subjected to the same environmental selection pressure.

Only healthy larvae randomly collected from several infrapopulations were carefully selected under a stereomicroscope and placed in a defined, complex specific culture medium follow Perteguer et al. (1996). A fter $7 \mathrm{~d}$ culture, the larvae were removed and fixed in hot $70 \%$ ethanol. Worms were examined at intervals of $24 \mathrm{~h}$, and the number that had completed ecdysis was counted. The ecdysis was used as a measure of development (Sommerville \& Davey 1976).

In vitro cultures were also performed to test the influence of the host source on excretory/secretory (ES) larval products. After 3 and $7 \mathrm{~d}$ culture, the supernatants were collected: ES1, 1 to $3 \mathrm{~d}$ and ES2, 4 to $7 \mathrm{~d}$. After dialysing against PBS and concentration in an Amicon YM-10, the protein content was estimated (Bradford 1976) and the supernatant was finally frozen at $-80^{\circ} \mathrm{C}$ until use. Sodium dodecylsulphate-polyacrylamide gel electrophoresis (SDS-PAGE) with ES products of third stage (L3) worm larvae was carried out (Laemmli 1970, Hames 1986) using a Mini Protean ${ }^{\circledR}$ cell (BioRad). The gel consisted of a $4 \%$ stacking gel and a 5 to $20 \%$ lineal gradient separating gel, under reducing conditions (García-Palacios et al. 1996). Broad range molecular weight markers ( 150 to $15 \mathrm{kDa}$, BioRad) were incorporated into each electrophor- etic run. The gels were stained with a silver staining kit (BioRad), following the manufacturer's instructions.

\section{RESULTS}

\section{PCR-RFLP analysis}

The amplification of the rDNA region spanning the ITS- 1 , ITS- 2 and the 5.8 subunit produced a fragment of $\sim 1 \mathrm{~kb}$. Fig. 1 shows the length of rDNA fragments of Anisakis simplex L3 digested with 6 different enzymes. Restriction with Alul produced 4 fragments of approximately 450, 240, 180 and $100 \mathrm{bp}$. Restriction with $\mathrm{Hhal}$ produced 2 fragments of approximately 550 and $430 \mathrm{bp}$. Restriction with $\mathrm{Hinfl}$ produced 2 fragments of approximately 620 and 250 bp plus a fragment shorter than $100 \mathrm{bp}$. Restriction with Rsal produced 4 bands (550, $300,125 \mathrm{bp}$, plus a fragment shorter than $100 \mathrm{bp}$ ). Restriction with Taql produced 3 bands $(430,400$ and $100 \mathrm{bp}$ ) and $\mathrm{M} \mathrm{bol}$ produced 3 bands (430, 430 and $100 \mathrm{bp}$ ). Few fragments of small size were also visible on the gel, but their resolution on the gel was not sufficient to determine exact sizing, thus not affecting the reliability of the assay. Restriction patterns allowed the specific identification of all the specimens analysed as corresponding to the sibling A. simplex s. str. (Table 1). M oreover, no variation in restriction patterns were observed among individual larvae of wild A. simplex s. str. collected from Micromesistius poutassou, Trachurus trachurus and Todaropsis eblanae. However, some differences were observed due to partial digestion of the amount of DNA, for example see Fig. 1D, lanes 2,4 and 6 .

\section{Morphometric analysis}

Data on larval morphometrics are given in Table 2. Larvae collected from Todaropsis eblanae were smaller in overall length than those collected from Micromesistius poutassou and Trachurus trachurus.

Table 1. Taxonomic key based on 3 diagnostic restriction enzymes (Hhal, Taql and Hinfl) for the identification of sibling species of the complex A nisakis simplex (adapted from D'A melio et al. 2000)

\begin{tabular}{|lll|}
\hline Enzyme & Fragments & Species \\
\hline Hinfl & $370-300-250$ & A. pegreffii \\
& $620-250-80$ & A. simplex sensu stricto and A. simplex C \\
Taql & $400-320-150$ & A. pegreffii \\
& $430-400-100$ & A. simplex sensu stricto and A. simplex C \\
Hhal & $550-430$ & A. simplex sensu stricto \\
& $550-300-130$ & A. simplex C \\
\hline
\end{tabular}



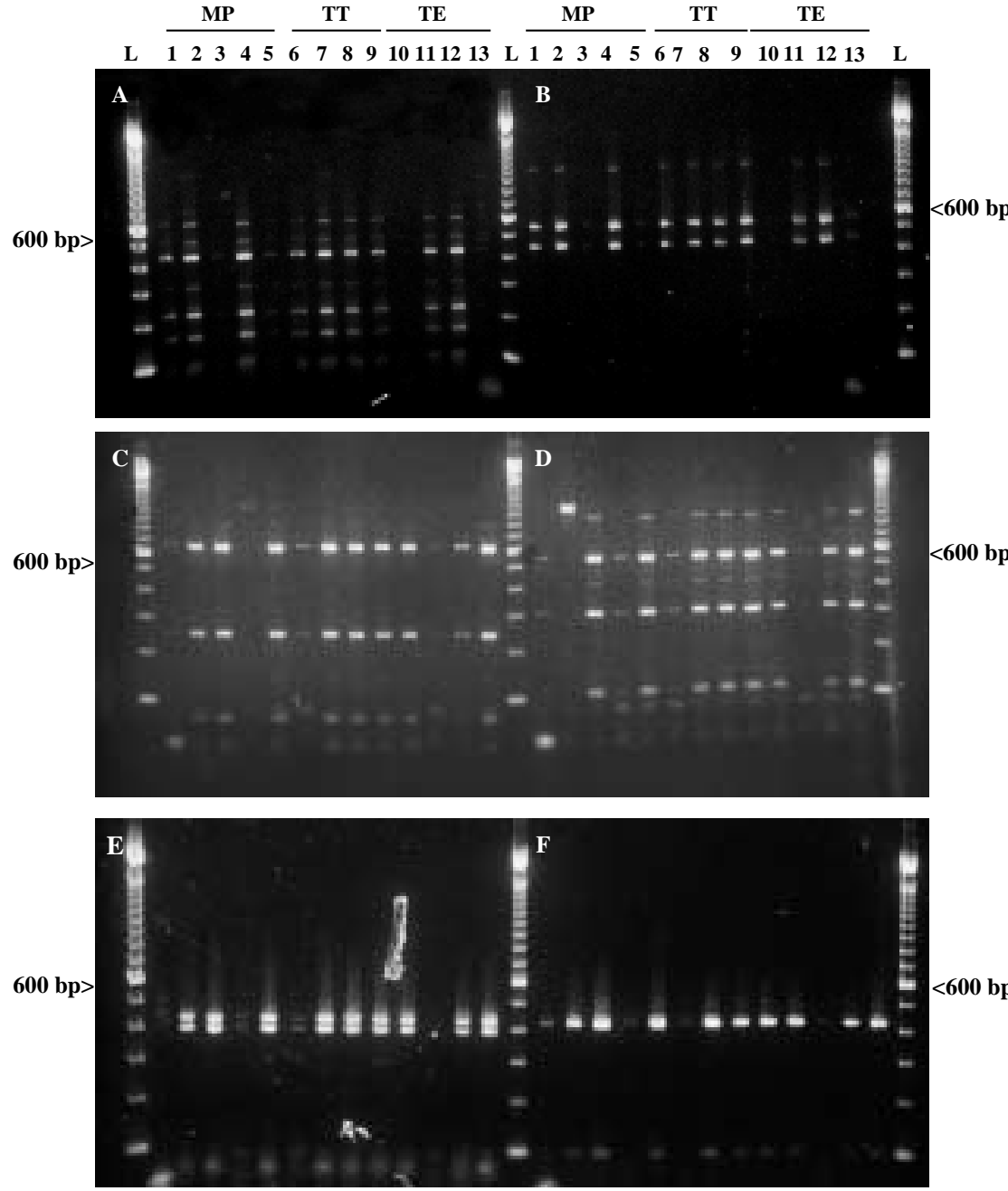

Fig. 1. Anisakis simplex s.str. Restriction fragment polymorphisms of larvae from 3 different paratenic hosts. rDNA digested with (A) Alul, (B) Hhal, (C) Hinfl, (D) Rsal, (E) Taql, (F) Mbol. Lanes 1-5: larvae from $\mathrm{M}$ icromesistius poutassou. Lanes 6-9: larvae from Trachurus trachurus. Lanes 10-13: larvae from Todaropsis eblanae. M P, M. poutassou; TT, T. trachurus; TE, T. eblanae; L, 100 bp ladder

M orphometric data showed that larval infrapopulation from T. eblanae are more homogenous that those from M. poutassou and T. trachurus. Thus $41.7 \%$ of the morphometric variables of A nisakis simplex s.str. larvae collected from $\mathrm{T}$. eblanae are conservative $(\mathrm{CV}<$ $10 \%$ ); $25 \%$ and $33.3 \%$ of the morphometric variables were conservative for larvae collected from $M$. poutassou and $\mathrm{T}$. trachurus respectively.

The values of the non-parametric and ANCOVA tests showed the influence of the host source in various morphometric characters (especially for $\mathrm{MN}$ and $\alpha$ index, which are conservative in larvae collected at any of the 3 host species) (Table 3 ) and growth patterns (Table 4). An a priori stepwise forward discriminant analysis showed 7 variables that were used in the canonical discriminant analysis. The eigenvalues for the 2 discriminant functions were 1.40 and 0.63 . The 2 roots accounted for 69 and $31 \%$ of the variance respectively. Calculation of $\mathrm{M}$ ahalanobis distance for individual cases revealed $81.33 \%$ discrimination between wild Anisakis simplex s. str. larvae from the 3 host sources as seen by the classification matrix (Table 5).

\section{'In vitro' culture}

After $7 \mathrm{~d}$ culture, no statistically significant differences $(p>0.005)$ were observed in any of the morphometric characters in larvae from the 3 host species (Table 3). Nevertheless, unequal mortality was observed. Thus, over 20 to $25 \%$ of the larvae collected from Micromesistius poutassou and Trachurus trachurus died earlier, up to the Day 7 of the experiment, whereas in the case of squid nematodes, the mortality increased to $80 \%$. Larvae from Todaropsis eblanae died $3 \mathrm{~d}$ before in culture and in the remaining larvae, the third ecdysis lagged until $10 \mathrm{~d}$; even then, the moult was $<600 \mathbf{b p}$ not completed in most of these larvae.

\section{SDS-PAGE analysis}

The banding patterns of ES1 of L3 collected from different host species were similar. ES1 were separated into major bands in the 75 to $15 \mathrm{kDa}$ range and an additional 4 bands within the $\geq 150 \mathrm{kDa}$ range (Fig. 2). Nevertheless, the banding patterns of the ES2 products differed considerably between the larvae collected from both fish hosts and the squid host. The ES2 antigen lanes of larvae collected from Micromesistius poutassou and Trachurus trachurus revealed 8 different bands that were not observed in the banding pattern of the ES2 larval products from Todaropsis eblanae. Furthermore, the banding pattern of ES2 products of larvae from $\mathrm{T}$. eblanae was very similar to the observed ES1 products, except for those bands within the $\geq 150 \mathrm{kDa}$ range.

\section{DISC USSION}

In temperate waters of the NE Atlantic the Anisakis simplex complex is considered a highly successful parasite, as it is suggested to be the most prevalent (an 
Table 2. Anisakis simplex s. str. Comparative morphometric data; mean \pm SD (range). Larvae collected from different paratenic hosts in temperate waters off the NE Atlantic

\begin{tabular}{|c|c|c|c|}
\hline Variable & $\begin{array}{c}\text { Micromesistius } \\
\text { poutassou }\end{array}$ & $\begin{array}{l}\text { Trachurus } \\
\text { trachurus }\end{array}$ & $\begin{array}{c}\text { Todaropsis } \\
\text { eblanae }\end{array}$ \\
\hline$B L$ & $\begin{array}{c}24.66 \pm 3.27 \\
(19.40-30.57)\end{array}$ & $\begin{array}{c}24.21 \pm 3.50 \\
(19.48-30.27)\end{array}$ & $\begin{array}{c}23.15 \pm 2.33 \\
(18.51-28.56)\end{array}$ \\
\hline BW & $\begin{array}{c}0.44 \pm 0.06 \\
(0.30-0.53)\end{array}$ & $\begin{array}{c}0.42 \pm 0.07 \\
(0.30-0.56)\end{array}$ & $\begin{array}{c}0.43 \pm 0.05 \\
(0.30-0.53)\end{array}$ \\
\hline OL & $\begin{array}{c}2.29 \pm 0.21 \\
(1.71-2.62)\end{array}$ & $\begin{array}{c}2.25 \pm 0.26 \\
(1.86-2.95)\end{array}$ & $\begin{array}{c}2.05 \pm 0.16 \\
(1.68-2.29)\end{array}$ \\
\hline OW & $\begin{array}{c}0.11 \pm 0.01 \\
(0.08-0.13)\end{array}$ & $\begin{array}{c}0.13 \pm 0.02 \\
(0.09-0.16)\end{array}$ & $\begin{array}{c}0.12 \pm 0.01 \\
(0.10-0.13)\end{array}$ \\
\hline VL & $\begin{array}{c}1.06 \pm 0.14 \\
(0.76-1.33)\end{array}$ & $\begin{array}{c}1.02 \pm 0.14 \\
(0.79-1.27)\end{array}$ & $\begin{array}{c}1.03 \pm 0.11 \\
(0.79-1.25)\end{array}$ \\
\hline VW & $\begin{array}{c}0.17 \pm 0.05 \\
(0.09-0.25)\end{array}$ & $\begin{array}{c}0.21 \pm 0.03 \\
(0.15-0.27)\end{array}$ & $\begin{array}{c}0.21 \pm 0.03 \\
(0.13-0.24)\end{array}$ \\
\hline TL & $\begin{array}{c}0.12 \pm 0.02 \\
(0.08-0.16)\end{array}$ & $\begin{array}{c}0.14 \pm 0.02 \\
(0.10-0.17)\end{array}$ & $\begin{array}{c}0.12 \pm 0.10 \\
(0.07-0.14)\end{array}$ \\
\hline $\mathrm{MN}$ & $\begin{array}{c}0.30 \pm 0.02 \\
(0.26-0.34)\end{array}$ & $\begin{array}{c}0.30 \pm 0.02 \\
(0.25-0.33)\end{array}$ & $\begin{array}{c}0.28 \pm 0.01 \\
(0.26-0.32)\end{array}$ \\
\hline$\alpha$ & $\begin{array}{c}57.00 \pm 5.48 \\
(42.73-64.38)\end{array}$ & $\begin{array}{c}58.55 \pm 5.56 \\
(46.57-70.44)\end{array}$ & $\begin{array}{c}54.36 \pm 3.90 \\
(48.77-62.70)\end{array}$ \\
\hline$\beta$ & $\begin{array}{c}10.80 \pm 1.28 \\
(7.84-14.04)\end{array}$ & $\begin{array}{c}10.87 \pm 0.89 \\
(9.79-12.40)\end{array}$ & $\begin{array}{c}11.33 \pm 0.98 \\
(9.14-13.00)\end{array}$ \\
\hline$\beta_{3}$ & $\begin{array}{c}23.32 \pm 2.56 \\
(19.08-27.10)\end{array}$ & $\begin{array}{c}23.69 \pm 2.32 \\
(19.98-30.27)\end{array}$ & $\begin{array}{c}22.58 \pm 2.46 \\
(19.14-27.86)\end{array}$ \\
\hline$\gamma$ & $\begin{array}{c}218.11 \pm 41.17 \\
(137.19-305.19)\end{array}$ & $\begin{array}{c}179.35 \pm 34.65 \\
(122.71-269.05)\end{array}$ & $\begin{array}{c}202.38 \pm 39.50 \\
(148.10-335.92)\end{array}$ \\
\hline
\end{tabular}

average of $60 \%$ mean occurrence in all host species examined) and numerically dominant macroparasite in commercial fishes. Worm counts of 7 (up to 100) larvae per host individual have been recorded. In fact, lifecycle traits of A. simplex s. str. in this geographic area revealed a well-adapted marine parasite, conspicuous at the free-living stage, cryptic at L3 in intermediate and paratenic hosts, eurixenous, moderately pathogenic and aggregately distributed within host populations (A bollo 1999). Such a scheme is of a parasite-host system in which parasite fitness will increase and selective pressures are primarily on the host (Combes
Table 3. Anisakis simplex s. str. Values of the Kruskall-Wallis test to estimate the influence of the host source on the morphometric characters of wild and cultured larvae. ns: not significant

\begin{tabular}{|c|c|c|c|c|}
\hline Variable & & $\chi^{2}$ & df & $p$ \\
\hline $\mathrm{BL}$ & $\begin{array}{l}\text { Wild } \\
\text { Cultured }\end{array}$ & $\begin{array}{l}1.8723 \\
1.9171\end{array}$ & $\begin{array}{l}2 \\
2\end{array}$ & $\begin{array}{l}\text { ns } \\
\text { ns }\end{array}$ \\
\hline BW & $\begin{array}{l}\text { Wild } \\
\text { Cultured }\end{array}$ & $\begin{array}{l}1.1684 \\
3.0659\end{array}$ & $\begin{array}{l}2 \\
2\end{array}$ & $\begin{array}{l}\text { ns } \\
\text { ns }\end{array}$ \\
\hline OL & $\begin{array}{l}\text { Wild } \\
\text { Cultured }\end{array}$ & $\begin{array}{r}13.8072 \\
4.8969\end{array}$ & $\begin{array}{l}2 \\
2\end{array}$ & $\begin{array}{c}<0.001 \\
\text { ns }\end{array}$ \\
\hline OW & $\begin{array}{l}\text { Wild } \\
\text { Cultured }\end{array}$ & $\begin{array}{r}14.7897 \\
0.5482\end{array}$ & $\begin{array}{l}2 \\
2\end{array}$ & $\begin{array}{c}<0.001 \\
\mathrm{~ns}\end{array}$ \\
\hline VL & $\begin{array}{l}\text { Wild } \\
\text { Cultured }\end{array}$ & $\begin{array}{l}1.2545 \\
2.0390\end{array}$ & $\begin{array}{l}2 \\
2\end{array}$ & $\begin{array}{l}\text { ns } \\
\text { ns }\end{array}$ \\
\hline VW & $\begin{array}{l}\text { Wild } \\
\text { Cultured }\end{array}$ & $\begin{array}{l}8.0936 \\
0.4613\end{array}$ & $\begin{array}{l}2 \\
2\end{array}$ & $\begin{array}{c}<0.05 \\
n s\end{array}$ \\
\hline $\mathrm{TL}$ & $\begin{array}{l}\text { Wild } \\
\text { Cultured }\end{array}$ & $\begin{array}{r}14.6755 \\
0.4105\end{array}$ & $\begin{array}{l}2 \\
2\end{array}$ & $\begin{array}{c}<0.001 \\
\mathrm{~ns}\end{array}$ \\
\hline $\mathrm{MN}$ & $\begin{array}{l}\text { Wild } \\
\text { Cultured }\end{array}$ & $\begin{array}{l}8.9397 \\
3.5531\end{array}$ & $\begin{array}{l}2 \\
2\end{array}$ & $\begin{array}{c}<0.05 \\
\text { ns }\end{array}$ \\
\hline$\alpha$ & $\begin{array}{l}\text { Wild } \\
\text { Cultured }\end{array}$ & $\begin{array}{l}8.7877 \\
1.2121\end{array}$ & $\begin{array}{l}2 \\
2\end{array}$ & $\begin{array}{c}<0.05 \\
n s\end{array}$ \\
\hline$\beta$ & $\begin{array}{l}\text { Wild } \\
\text { Cultured }\end{array}$ & $\begin{array}{l}4.3303 \\
0.2407\end{array}$ & $\begin{array}{l}2 \\
2\end{array}$ & $\begin{array}{l}\text { ns } \\
\text { ns }\end{array}$ \\
\hline$\beta_{3}$ & $\begin{array}{l}\text { Wild } \\
\text { Cultured }\end{array}$ & $\begin{array}{l}2.9822 \\
0.8752\end{array}$ & $\begin{array}{l}2 \\
2\end{array}$ & $\begin{array}{l}\text { ns } \\
\text { ns }\end{array}$ \\
\hline$\gamma$ & $\begin{array}{l}\text { Wild } \\
\text { Cultured }\end{array}$ & $\begin{array}{r}13.7182 \\
0.2359\end{array}$ & $\begin{array}{l}2 \\
2\end{array}$ & $\begin{array}{c}<0.001 \\
n s\end{array}$ \\
\hline
\end{tabular}

Table 4. Anisakis simplex s. str. ANCOVA values to compare allometric growth patterns of larvae collected from different host source. ns: not significant

\begin{tabular}{|lccc|}
\hline Variable & $\mathrm{F}$ & $\mathrm{df}$ & $\mathrm{p}$ \\
\hline BW & 4.626 & 2 & $<0.05$ \\
OL & 8.515 & 2 & $<0.001$ \\
OW & 15.181 & 2 & $<0.001$ \\
VL & 1.009 & 2 & $\mathrm{~ns}$ \\
VW & 13.480 & 2 & $<0.001$ \\
TL & 9.019 & 2 & $<0.001$ \\
MN & 3.680 & 2 & $<0.05$ \\
\hline
\end{tabular}

Table 5. Anisakis simplex s. str. Classification matrix displaying the number out of 75 larvae allocated to groups for which they have the minimum $M$ ahalanobis distance

\begin{tabular}{|lcrrrr|}
\hline Source group & \% correctly & \multicolumn{2}{c|}{ Number allocated to group } & \multirow{2}{*}{ Total } \\
& classified & T. eblanae & T. trachurus & M. poutassou & \\
\hline Todaropsis eblanae & 84 & 21 & 2 & 2 & 25 \\
Trachurus trachurus & 80 & 3 & 20 & 2 & 25 \\
Micromesistius poutassou & 80 & 3 & 2 & 20 & 25 \\
Sum & 81.33 & 27 & 24 & 24 & 75 \\
\hline
\end{tabular}




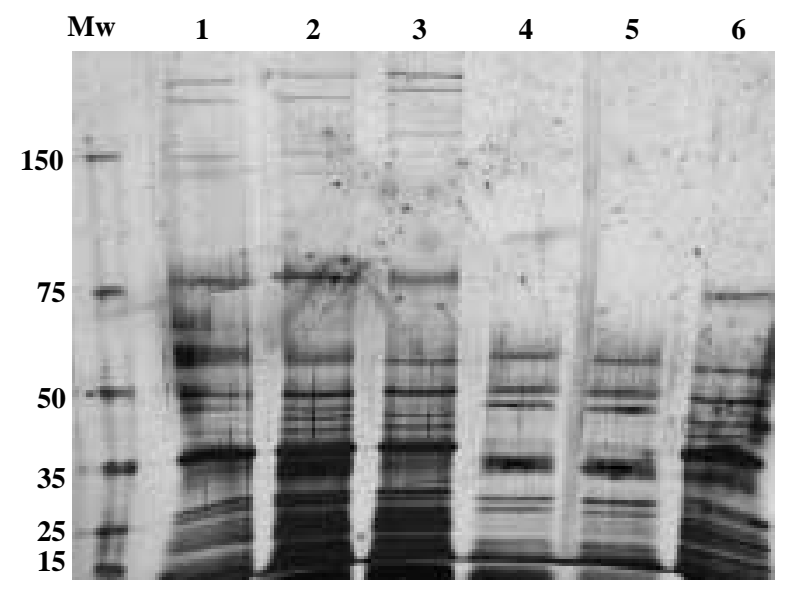

Fig. 2. A nisakis simplex s. str. SDS-PAGE of excretion/secretion antigens at $L 3$ collected from 3 different paratenic hosts. M w, molecular weight. Lane 1: ES1 of larvae from Micromesistius poutassou. Lane 2: ES1 of larvae from Trachurus trachurus. Lane 3: ES1 of larvae from Todaropsis eblanae. Lane 4: ES2 of larvae from M . poutassou. Lane 5: ES2 of larvae from

T. trachurus. Lane 6: ES2 of larvae from T. eblanae

1997). In addition to the specific identity of intermediate and definitive host (Nadler 1987), the main factors considered to induce intraspecific variability in anisakid nematodes are the geographical origin of host populations (George-Nascimento \& Llanos 1995) and the complexity of the life-cycle (Bullini et al. 1986). As a consequence of different selection pressures, the identification of morphological, biochemical and genetic markers has revealed substantial intraspecific variation within anisakids among different microenvironment types. This has been well documented in Contracaecum osculatum s.l. (Fagerholm 1989, Nascetti et al. 1993, Orecchia et al. 1994), Anisakis simplex s.l. (Threlfall 1982, Smith 1983b, Mattiucci et al. 1997, Siles et al. 1997, Pascual et al. 1999), and Pseudoterranova decipiens s.l. (Paggi et al. 1991, Bristow \& Berland 1992, George-Nascimento \& Llanos 1995).

Morphometric and growth variations among wild larvae collected from the 3 host sampled species agreed with the electrophoretic variations of ES2 products of larvae grown in vitro, which are known to be produced during invasion of the host's tissues (Raybourne et al. 1986). Since enzymes involved in tissuepenetration (ES1 in the present study) were similar in wild third-stage larvae from a squid or a fish host, these differences must arise from some other as yet unknown environmental pressure against those larvae inhabiting the invertebrate paratenic hosts. Data on ES2 patterns of larvae from a squid or fish host suggest different morphoanatomical developments and development timings on cultured larvae depending on host source. Consequently, Anisakis infrapopulations will have ontogenetic trajectories which will be different in larvae collected from each host species. Furthermore, the 3 host species sampled share the same sources of infection via diet (A bollo 1999) and the accumulation of infrapopulation worm larvae in the squid is determined by the combination of genotypes arriving from blue whiting and other different fish hosts ingested; these are shared between sympatric paratenic hosts in the sampling area, as noted by Pascual et al. (1996) and Rasero et al. (1996). Sugane et al. (1989) found that the patterns of 2 different fish paratenic host-derived DNA of Anisakis larvae type I were exactly the same in hybridised fragments generated by 6 endonucleases which reinforces the idea that Anisakis larva (I) genomic DNA from different paratenic host is not affected by environmental conditions.

The reasons for the differences in morphometric and growth pattern and also those in survival rates, and time of moult and ecdysis of larvae from squid and fish host, are not clear. Current views on the control of differentiation and growth of parasitic nematodes (Rogers $\&$ Sommerville 1968, Davey 1972) show that external stimuli activate internal regulatory mechanisms, including neurosecretions, which in turn generally regulate the various aspects of growth and differentiation, including moult and ecdysis behaviour in vitro. The external stimuli can be simple combinations of various components likely to be found in the alimentary tract of the host. Thus, the moult of exsheated third-stage larvae of A. simplex to an established parasite is probably initiated by temperature and carbon dioxide in the gas phase which reproduces some features of the stomach of the host (Sommerville \& Davey 1976). Perhaps freshly hatched encapsulated larvae are less able to grow in the physicochemical environment impaired by the squid gastrointestinal tract, possibly due to the inhibitory effect of larval activity. Nevertheless, this is not likely because of the similar physicochemical environment that larvae might encounter on passage through a squid or a fish host (Packard 1972). M oreover, even significant differences should not be expected in relation to host immunity. The tissue response to the presence of Anisakis in an ommastrephid squid or a teleost fish is typical of a chronic granulamatous inflammatory reaction, as described by Abollo et al. (1998) and Ramakrishna \& Burt (1991) respectively. The paratenic host encapsulates the parasite, preventing its continual migration and consequent destruction of tissues. It has been found that the capsules of 'later' and 'old' stages of infections differ in quantitative aspects, such as intensity of response and thickness of capsule (Ramakrishna \& Burt 1991). However, all larvae sampled here were collected from 'later' capsules showing a healthy aspect (shining and transparent cuticle) and vigorous movements. 
On the other hand, it was stated that those larvae that have been passed from fish to fish (i.e., from one paratenic host to another) may have insufficient energy stores or enzymes to establish in a new microenvironment, as was demonstrated experimentally by Wootten \& Smith (1975) and Burt et al. (1990). Worm larvae from the squid had naturally passes through at least one cephal opod (by cannibalism) and/or fish host (mainly Micromesistius poutassou but also Trachurus trachurus) used as prey to infect this host; the shortfinned squid are largely voracious piscivorous at mantle length $\geq 120 \mathrm{~cm}$ (Rasero et al. 1996). In the sampling area these larger, mature squids in which the wholeparasite recruitment takes place (Pascual et al. 1995, 1996, 1999) are mainly feeding (up to $60 \%$ of its diet) on heavily infected 20 to $26 \mathrm{~cm}$ blue whiting (Rasero et al. 1996). According to Wootten \& Smith (1975) and Burt et al. (1990), this may explain the low survival rate and moult success of squid larvae grown in vitro compared with those from a fish host. Schiemer (1987) stated that even small differences in energy transfer efficiencies and energy allocation patterns to perform adaptive functions can have profound effects on nematode fitness under certain habitat conditions. Besides the energetic cost through metabolic adaptations for host tissue invasion (i.e., the invasion of a new microenvironment), larvae inhabiting the squid may also have suffered a larger sequence of severe host responses than those from the 2 other fish hosts, which had probably acquired the infection directly by entering an invertebrate intermediate host.

We stated that in the sampling area, cephalopods (especially large ommastrephid squids) seem to be less favourable paratenic hosts for A nisakis simplex s. str. larvae than those fish species with a similar ecological niche. However, it should also be noted that cephalopods are a key trophic bridge in order for the parasitic life-cycle to be completed in the long-finned pilot whale (Abollo et al. 1998). Thus, the narrow trophic relationship which has been demonstrated between cephalopods and long-finned pilot whales should also be considered as an important element for understanding the widespread dissemination of Anisakis in all major seas and oceans, especially in those areas where no other potential small-cetacean final hosts are abundantly distributed.

Fitness is defined as 'the average contribution of one allele or genotype to the next generation or to succeeding generations, compared with that of other alleles or genotypes' (Futuyma 1986). We might assume that a higher rate of 'maladaptation' of Anisakis simplex s. str. larvae to the squid host in relation to the fish host (i.e. the observable morphometric, growth, biochemical and behavioural characteristics which impair the ability of worm larvae to survive and differentiate in a particular environment, thereby reducing their fitness) is not likely to be due to insufficient time for evolution by natural selection to take place. The high level of gene flow (Paggi \& Bullini 1994) and a heterogeneous environment may prevent larvae from being equally efficient in all paratenic host species. Furthermore, the first causes of variation may be changes in that part of the genome of the larvae that is expressed, or in that part that regulates expression. Thus the expression of proteinases that play an important role in the invasion of host tissues (Hotez et al. 1994), parasite nutrition (McKerrow 1989), secretion of pharmacological mediators (Rhoads 1984) and suppression of host immune responses (Leid et al. 1987) is often developmentally regulated (Newport et al. 1988).

Our experiments show that the squid host reduces growth and differentiation times of Anisakis simplex s.str. larvae. But perhaps of greater interest is the demonstration that parasite recruitment to the longfinned pilot whale, the final host in the sampling area, is expected to be reduced in those $L 3$ from this invertebrate paratenic host that has obviously negative effects on parasite fitness.

Acknowledgements. The authors are grateful to Consellería de Educación e Ordenación Universitaria, Xunta de Galicia for financial support, under the project XUGA 30110A97.

\section{LITERATURE CITED}

Abollo E (1999) Anisáquidos en aguas de Galicia: del gen al ecosistema. PhD Universidad de Vigo

Abollo E, Gestal C, López A, González AF, Guerra A, Pascual $S$ (1998) Squid as trophic bridges for parasite flow within marine ecosystems: the case of Anisakis simplex (Nematoda: A nisakidae), or when the wrong way can be right. In: Payne AIL, Lipinski MR, Clarke MR, Roeleveld MAC (eds) Cephalopod biodiversity, ecology and evolution, Vol 20. S Afr J Mar Sci, p 223-232

Bachellerie JP, LU Qu (1993) Ribosomal RNA probes for detection and identification of species. In: Hyde JE (ed) Protocols in molecular parasitology. Humana Press, Totowa, NJ , p 249-263

Berland B (1961) Nematodes from some Norwegian marine fishes. Sarsia 2:1-50

Bradford MA (1976) A rapid and sensitive method for the quantification of microgram quantities of protein utilizing the principle protein-dye binding. Anal Biochem 72:248

Bristow GA, Berland B (1992) On the ecology and distribution of Pseudoterranova decipiens C (Nematoda: Anisakidae) in an intermediate host, Hippoglossoides platessoides, in northern Norwegian waters. Int J Parasitol 22:203-208

Bullini L, Nascetti G, Paggi L, Orecchia P, Mattiucci S, Berland B (1986) Genetic variation of ascaridoid worms with different life cycles. Evolution 40:437-440

Burt MDB, Campbell J D, Likely CG, Smith JW (1990) Serial passage of larval Pseudoterranova decipiens (Nematoda: Ascaridoidea) in fish. Can J Fish Aquat Sci 47:693-695

Combes C. (1997) Fitness of parasites: pathology and selection. Int J Parasitol 27 (1):1-10 
D'Amelio S, Mathiopoulos KD, Santos CP, Pugachev ON, Webb SC, Picancpo M , Paggi, L (2000) Genetic markers in ribosomal DNA for the identification of members of the genus Anisakis (Nematoda: Ascaridoidea) defined by polymerase chain reaction-based restriction fragment length polymorphism. Int J Parasitol 30:223-226

Davey KG (1972) Hormones, the environment and development in nematodes. In: Van de Bosche (ed) Comparative biochemistry of parasites. Academic Press, New York, p 81-94

Des Clers S (1990) Modelling the life cycle of the sealworm (Pseudoterranova decipiens) in Scottish waters. In: Bowen WD (ed) Population biology of sealworm (Pseudoterranova decipiens) in relation to its intermediate and seal hosts. Can Bull Fish Aquat Sci 222:273-288

Fagerholm HP (1979) Nematode length and preservatives, with a method for determining the length of live specimens. J Parasitol 65:334-335

Fagerholm HP (1989) Intra-specific variability of the morphology in a single population of the seal parasite Contracaecum osculatum (Rudolphi) (Nematoda: Ascaridoidea), with a redescription of the species. Zool Scr 18:33-41

Futuyma DJ (1986) Evolutionary biology. Sinauer Associates, Sunderland, MA

García-Palacios L, González ML, Esteban MI, Mirabent E, Perteguer MJ , Cuéllar C (1996) Enzyme-linked immunosorbent assay, immunoblot analysis and RAST fluoroimmunoassay analysis of serum responses against crude larval antigens of Anisakis simplex in a Spanish random population.J Helminthol 70:281-289.

George-Nascimento M, Llanos A (1995) Micro-evolutionary implications of allozymic and morphometric variations in sealworms Pseudoterranova sp. (Ascaridoidea: Anisakidae) among sympatric hosts from the Southeastern Pacific Ocean. Int J Parasitol 25(10):1163-1171

Hames BD (1986) An introduction to polyacrylamide gel electrophoresis. In: Hames BD, Rickwood D (eds) Gel electrophoresis of proteins. IRL Press, Oxford, p 21-57

Holmes DS, Bonner J (1973) Preparation, molecular weight, base composition, and secondary structure of giant nuclear ribonucleic acid. Biochemistry 12 (12):2330-2338

Hotez P, Cappelo M, Hawdon J, Beckers C, Sakanari J (1994) Hyaluronidases of the gastrointestinal invasive nematodes Ancylostoma caninum and Anisakis simplex: possible functions in the pathogenesis of human zoonoses. J Infect Dis 170:918-926

ICES-WGPDM OC (1995) ICEs Working Group on Pathology and Diseases of M arine Organisms Committee. ICES CM 1995/F, M ariculture Committee

Koyama T, Kobayashi A, Kumada M, Komiya Y, Oshima T, Kagei N, Ishi T, M achida M (1969) M orphological and taxonomical studies on Anisakidae larvae found in marine fish and squids. J pn J Parasitol 18:466-487

Laemmli EK (1970) Cleavage of structural proteins during the assembly of the head of bacteriophage T4. Nature 277: 680-685.

Leid RW, Suquet CM, Tanigoshi L (1987) Parasite defence mechanisms for the evasion of host immune responses. Vet Parasitol 25:147-162

Likely CG, Burt MD (1989) Cultivation of Pseudoterranova decipiens (sealworm) from third-stage larvae to egg-laying adults in vitro. Can J Fish Aquat Sci 46 (7):1095-1096

Mattiucci M, Nascetti G, Cianchi R, Paggi L, Arduino P, Margolis L, Brattey J , Webb S, D'A melio S, Orecchia P, Bullini $L$ (1997) Genetic and ecological data on the Anisakis simplex complex, with evidence for a new species (Nematoda, Ascaridoidea, Anisakidae). J Parasitol 83 (3):401-416
McKerrow JH (1989) Parasite proteases. Exp Parasitol 68: 11-115

Nadler S (1987) Genetic variability in endoparasitic helminths. Parasitology Today 3:154-157

Nascetti G, Paggi L, Orecchia P, Mattiucci S, Bullini L (1983) Two sibling species within Anisakis simplex (Ascaridida: Anisakidae). Parassitologia 25:239-241

Nascetti G, Paggi L, Orecchia P, Smith J, Mattiucci S, Bullini $L$ (1986) Electrophoretic studies on the Anisakis simplex complex (Ascaridida: Anisakidae) from the Mediterranean and North-East Atlantic. Int J Parasitol 16:633-640

Nascetti G, Cianchi R, Mattiucci S, D'Amelio S, Orecchia $P$, Paggi L, Brattey J , Berland B, Smith J W, Bullini L (1993) Three sibling species within Contracaecum osculatum (Nematoda, Ascaridida, Ascaridoidea) from the Atlantic Arctic-Boreal region: reproductive isolation and host preferences. Int J Parasitol 23:105-120

Newport GR, McKerrow J H, Hestrom R, Petit M, M cGarrigle L, Barr PJ , Agabian N (1988) Cloning of the proteinase that facilitated infection by Schistosome parasites. J Biol Chem 263:13179-13184

Orecchia P, M attiucci S, D'A melio S, Paggi L, Plötz J , Cianchi R, Nascetti G, Arduino P, Bullini L (1994) Two new members in the Contracaecum osculatum complex (Nematoda, Ascaridoidea) from the Antarctic. Int J Parasitol 24(3): 367-377

Packard A (1972) Cephalopods and fish: the limits of convergence. Biol Rev 47:241-307

Paggi L, Bullini L (1994) Molecular taxonomy in anisakids. Bull Scand Soc Parasitol 4(2):25-39

Paggi L, Nascetti G, Cianchi R, Orecchia P, Mattiucci S, D'Amelio S, Berland B, Brattey J, Smith JW, Bullini L (1991) Genetic evidences for three species within Pseudoterranova decipiens (Nematoda, Ascaridida, Ascaridoidea) in the North Atlantic and Norwegian and Barents Seas. Int J Parasitol 21:195-212

Pascual S, Rasero M, Arias C, Guerra A (1995) Helminthfauna of the short-finned squid Todaropsis eblanae (Ball, 1841) (Cephalopoda: Ommastrephidae) off NW Spain. Res Rev Parasitol 55(2):1-4

Pascual S, González AF, Arias C, Guerra A (1996) Biotic relationships of Illex coindetii and Todaropsis eblanae (Cephalopoda, Ommastrephidae) in the Northeastern Atlantic: evidence from parasites. Sarsia 81:265-274.

Pascual S, González AF, Arias C, Guerra A (1999) Larval Anisakis simplex B (Nematoda: Ascaridoidea) of shortfinned squid (Cephalopoda: Ommastrephidae) in northwest Spain. J Mar Biol Assoc UK 79:65-72

Pavlovski EW (1934) Organisms as environment. Priroda (M oscow) I:80-91 (in Russian)

Perteguer MJ , Raposo R, Cuéllar C (1996) In vitro studies on the effect of larval excretory/secretory productes and crude extracts from Anisakis simplex on blood coagulation. Int J Parasitol 26(1):105-108

Ramakrishna NR, Burt MDB (1991) Tissue response of fish to invasion by larval Pseudoterranova decipiens (Nematoda; Ascaridoidea). Can J Aquat Sci 48:1623-1628

Rasero M, González AF, Castro BG, Guerra A (1996) Pedratory relationships of two sympatric squid, Todaropsis eblanae and Illex coindetii (Cephalopoda: Ommastrephidae) in Galician waters. J Mar Biol Assoc UK 76:73-87

Raybourne R, Deadorff TL, Bier J W (1986) Anisakis simplex: larval excretory secretory protein production and cytostatic action in mammalian cell cultures. Exp Parasitol 62:92-97

Rhoads ML 1984. Secretory cholinesterases of nematodes: possible functions in the host-parasite relationship. Trop Vet 2:3-10 
Rogers WP, Sommerville RJ, (1968) The infectious process and its relation to the development of early parasitic stages of nematodes. Adv Parasitol 6:327-348

Schiemer F (1987) Nematoda. In: Pandian TJ, Vernberg FJ (eds) Animal energetics. Academic Press, San Diego, p 185-211

Siles M, Cuéllar C, Perteguer MJ (1997) Genomic identification of Anisakis simplex isolates. J Helminthol 71:73-75

Smith J W (1974) Experimental transfer of A nisakis sp. Iarvae (Nematoda: Ascaridida) from one fish host to another. J Helminthol 48:229-234

Smith JW (1983a) Larval Anisakis simplex (Rudolphi 1809, det Krabbe, 1878) and larval Hysterothylacium sp. (Nematoda: Ascaridoidea) in euphausiids (Crustacea: Malacostraca) in the North-East Atlantic and northern North Sea. J Helminthol 57:167-177

Smith JW (1983b) Anisakis simplex (Rudolphi, 1809, det. Krabbe, 1878) (Nematoda: Ascaridoidea): morphology and morphometry of larvae from euphausiids and fish, and a review of the life-history and ecology. J Helminthol 57: 205-224

Editorial responsibility: Wolfgang Körting, Hannover, Germany
Smith JW (1984) Anisakis simplex (Rudolphi, 1809, det. Krabbe, 1878): length distribution and viability of L3 of known minimun age from herring Clupea harengus $L$. J Helminthol 58:337-340.

Sommerville RI, Davey KG (1976) Stimuli for cuticle formation and ecdysis in vitro the infective larva of Anisakis sp. (Nematoda: Ascaridoidea). Int J Parasitol 6:433-439

Sugane K, Qing L, Matsuura T (1989) Restriction fragment length polymorphisms of Anisakinae larvae. J Helminthol 63:269-274

Threlfall W (1982) In vitro culture of A nisakis spp. Iarvae from fish and squid in Newfoundland. Proc Helminthol Soc Wash 49(1):65-70

Valero A, De Renzi M, Mas-Coma S (1991) Ontogenetic trajectories: a new approach in the study of parasite development, with special reference to Digenea. Res Rev Parasitol 51(1-4):125-138

Wootten R, Smith J W (1975) Observational and experimental studies on the acquisition of Anisakis sp. larvae (Nematoda: Ascaridida) by trout in fresh water. Int J Parasitol 5: 373-378

Submitted: November 6, 2000; Accepted: February 22, 2001 Proofs received from author(s): M ay 31, 2001 